\title{
Penerapan Problem Based Learning Tipe CPS untuk Meningkatkan Kemampuan Pemecahan Masalah Matematika Siswa Sekolah Dasar
}

Received:

$11 / 12 / 2021$

Accepted:

$17 / 12 / 2021$

Published:

31/12/2021

\author{
${ }^{1}$ Hamdana Hadaming, ${ }^{2}$ Andi Ardhila \\ Universitas Muhammadiyah Makassar, Makassar, Indonesia \\ 1hamdana@unismuh.ac.id
}

\begin{abstract}
This study aims to determine the effect of applying the CPS Type Problem Based Learning learning model on solving math problems for fifth-grade students at Bawakaraeng Makassar State Elementary School. The research design used is The One Group Pretest-Posttest Design, which is a research design carried out with an initial test and a final test. The sampling model used is a non-random sampling technique using sampling technique. The population is fifth-grade students of Bawakaraeng Makassar State Elementary School with a research sample of 20 students in class fifth-grade. The research was carried out for 4 meetings. Data collection techniques used were learning outcomes tests to measure students' problem-solving skills before and after participating in learning using the Problem Based Learning CPS learning model, and student activity observation sheets to observe student activities during the learning process. So the results of the study showed that the average score of the pretest (Pretest) was 63 and there were 10 students (50\%) who completed it. While the average score of the final test (Posttest) for students' Mathematics learning outcomes is 83.25 and there are 16 students $(80 \%)$ in the complete category. Based on the results of the study, the application of the CPS Type Problem Based Learning learning model affects solving mathematical problems in fifth-grade students of Bawakaraeng Makassar State Elementary School.
\end{abstract}

Keywords: Mathematical problem solving; Mathematics; Problem Based Learning Type CPS.

\begin{abstract}
Abstrak
Penelitian ini bertujuan untuk mengetahui pengaruh model pembelajaran Problem Based Learning Tipe CPS terhadap kemampuan pemecahan masalah matematika siswa kelas V SD Negeri Bawakaraeng Makassar. Desain penelitian yang digunakan adalah The One Group Pretest-Posttest Design, yaitu sebuah desain penelitian yang dilaksanakan dengan adanya tes awal dan tes akhir. Model pengambilan sampel yang digunakan adalah teknik non random sampling menggunakan teknik sampling. Populasinya adalah siswa kelas V SD Negeri Bawakaraeng Makassar dengan sampel penelitian yaitu siswa kelas V sebanyak 20 siswa. Penelitian dilaksanakan selama 4 kali pertemuan. Teknik pengumpulan data yang digunakan adalah tes hasil belajar untuk mengukur kemampuan pemecahan masalah siswa sebelum dan setelah mengikuti pembelajaran dengan menggunakan model pembelajaran Problem Based Learning Tipe CPS, dan lembar observasi aktivitas siswa untuk mengamati aktivitas siswa selama proses pembelajaran berlangsung. Maka hasil penelitian menunjukkan bahwa skor rata-rata tes awal (Pretest) adalah 63 dan terdapat 10 siswa $(50 \%)$ yang tuntas. Sedangkan skor rata-rata tes akhir (Posttest) hasil belajar Matematika siswa yaitu 83,25 dan terdapat 16 siswa
\end{abstract}


$(80 \%)$ berada pada kategori tuntas. Berdasarkan hasil penelitian maka penerapan model pembelajaran Problem Based Learning Tipe CPS berpengaruh terhadap kemampuan pemecahan masalah matematika pada siswa kelas $\mathrm{V}$ SD Negeri Bawakaraeng Makassar.

Kata kunci: Matematika; Pemecahan Masalah Matematika; Problem Based Learning Tipe CPS

\section{Pendahuluan}

Matematika merupakan mata pelajaran yang di ajarkan mulai dari sekolah dasar sampai dengan perguruan tinggi. Hal ini menunjukan bertapa pentingnya peran matematika dalam dunia pendidikan dan perkembangan teknologi sekarang ini. Pembelajaran matematika di sekolah dasar merupakan dasar bagi penerapan konsep matematika pada jenjang berikutnya (Fahrudin et al., 2018). Pentingnya peranan matematika juga terlihat pada pengaruh terhadap mata pelajaran lain seperti mata pelajaran geografi, fisika, dan kimia. Jadi Dapat di simpulkan bahwa matematika memiliki peran yang sangat penting khususnya di sekolah dasar (Winarso, 2014).

Ada beberapa alasan penting mengapa sistem pengajaran ini perlu dipakai lebih sering di sekolah. Seiring dengan proses globalisasi, juga terjadi transformasi sosial, ekonomi, dan demografis yang mengharuskan sekolah untuk lebih menyiapkan siswa dengan keterampilan-keterampilan baru untuk bisa ikut berpartisipasi dalam dunia yang berubah dan berkembang pesat (Suhardi, 2019). Adanya transformasi sosial pun mengharuskan para siswa untuk memiliki jiwa sosial yang tinggi sehingga pembelajaran yang dilaksanakan akan bermakna dan memiliki daya saing yang sehat.

Berdasarkan observasi yang dilakukan di Sekolah Dasar Negeri Bawakaraeng Makassar, beberapa siswa yang beranggapan bahwa matematika merupakan mata pelajaran yang di anggap sulit dan membosankan untuk di pelajari. Di tambah sangat minimnya kemampuan siswa dalam memecahkan masalah matematika. Selain itu, pembelajaran hanya berfokus pada guru. Siswa hanya dituntut untuk mengetahui konsep yang di berikan guru tanpa melibatkan langsung dalam menemukan konsep tersebut sehingga siswa merasa kesulitan dalam menyelesaikan soal-soal yang diberikan dalam pembelajaran matematika. Dengan KKM 65 pada mata pelajaran Matematika masih banyak siswa yang tidak mencapai KKM tersebut, rata-rata nilai siswa masih dibawah KKM yaitu 55,67.

Rendahnya hasil belajar Matematika pada siswa kelas V tersebut disebabkan oleh beberapa faktor diantaranya: (1) proses pembelajaran masih sangat monoton belum mencoba menggunakan metode atau model pembelajaran yang inovatif masih menggunakan metode ceramah; (2) kurangnya mengoptimalkan partisipasi siswa dalam menjawab pertanyaan pada proses pembelajaran; dan (3) kurang memberikan kesempatan kepada siswa untuk menunjukkan partisipasi mereka kepada orang lain. Oleh karena itu, penulis disini mengkaji kemampuan pemecahan masalah dengan menerapkan model Problem Based Learning Tipe CPS dengan membangun sendiri pengetahuan sehingga dapat memecahkan masalah dari apa yang di pelajarinya kemudian menerapkannya dikehidupan nyata mereka. Salah satu caranya yaitu dengan 
menerapkan model pembelajaran yang tepat, Sehingga di harapkan hasil pembelajaran matematika yang lebih bermutu dan berkualitas dapat di proleh dengan baik.

Model pembelajaran CPS adalah suatu model pembelajaran yang memusatkan pada pengajaran dan keterampilan pemecahan masalah, yang diikuti dengan penguatan keterampilan (Asikin et al., 2011). Dengan memecahkan sebuah masalah dapat membantu siswa berfikir kritis (Daniel, 2017; Wiratman et al., 2019). Model pembelajaran ini diharapkan dapat meningkatkan ketuntasan belajar serta aktvitas siswa dalam mempelajari matematika, sehingga siswa dapat memperoleh manfaat yang maksimal baik dari proses maupun hasil belajarnya.

Model pembelajaran CPS memiliki ciri-ciri seperti pembelajaran dimulai dengan pemberian masalah, masalah memiliki konteks dengan dunia nyata, siswa secara berkelompok aktif merumuskan masalah dan mengidentifikasi kesenjangan pengetahuan mereka, mempelajari dan mencari sendiri materi yang terkait dengan masalah dan melaporkan solusi dari masalah (Ginting et al., 2019; Rahman et al., 2015). Sementara pendidik lebih banyak memfasilitasi (Adelia et al., 2020).

Hasil penelitian (Ginting et al., 2019) juga menyimpulkan bahwa "model pembelajaran CPS memberikan pengaruh lebih efektif dibandingkan dengan model pembelajaran konvensional. Hal ini dapat dilihat dari perbedaan antara nilai rata-rata posttest kelas eksperimen yang cenderung lebih tinggi dibandingkan dengan rata-rata posttest kelas kontrol."

Berdasarkan uraian diatas peneliti tertarik untuk menerapkan model Problem Based Learning Tipe CPS dalam pembelajaran matematika di SD Negeri Bawakaraeng Makassar untuk meningkatkan kemampuan pemecahan masalah matematika siswa.

\section{Metode Penelitian}

Penelitian ini merupakan penelitian eksperimen dengan jenis penelitian praeksperimental design, yang mengkaji model model Problem Based Learning Tipe CPS dalam membantu siswa memahami pelajaran Matematika di kelas V SD Negeri Bawakaraeng Makassar. Desain Experimen yang digunakan adalah One-Group Pretest-Posttest Design. Desain ini digunakan karena penelitian ini hanya melibatkan satu kelompok saja tanpa ada kelompok pembanding yang sebelumnya telah diberikan perlakuan berupa tes awal sebelum perlakuan dan selanjutnya tes setelah diberikan perlakuan (Sugiyono, 2017). Secara umum model penelitian eksperimen ini disajikan sebagai berikut:

Tabel 1 Model Desain Penelitian

\begin{tabular}{ccc}
\hline Sebelum & Perlakuan & Sesudah \\
\hline$O_{1}$ & $\mathrm{X}$ & $\mathrm{O}_{2}$ \\
\hline
\end{tabular}

Keterangan:

$\mathrm{O}_{1}=$ nilai pretest (sebelum diberi perlakuan)

$\mathrm{O}_{2}=$ nilai posttest (sesudah diberi perlakuan)

$\mathrm{X}=$ perlakuan yang diberikan 
Teknik Pengumpulan Data yaitu untuk memperoleh data mengenai keaktifan siswa, dengan menggunakan lembar observasi aktivitas siswa. Untuk memperoleh data mengenai kemampuan pemecahan masalah matematika siswa diperoleh dari hasil belajar matematika siswa, dengan menggunakan teknik pemberian tes hasil belajar. Data yang telah terkumpul dengan menggunakan instrumen-instrumen yang ada kemudian dianalisis dengan menggunakan teknik analisis statistik deskriptif. Teknik analisis deskriptif digunakan untuk mengungkap keterlaksanaan pembelajaran, hasil belajar siswa dan keaktifan siswa selama pembelajaran, pembelajaran matematika dengan model Problem Based Learning Tipe CPS.

\section{Hasil dan Diskusi}

Dalam penelitian ini diperoleh beberapa data yaitu data hasil pengamatan keaktifan siswa, dan data hasil pretest sebelum diberikan perlakuan untuk mengukur sejauh mana tingkat kemampuan siswa dalam pembelajaran matematika dan data ketuntasan hasil belajar siswa setelah diberikan perlakuan (posttest). Adapun hasil analisis masing-masing data tersebut adalah sebagai berikut :

\section{Deskripsi Kemampuan Awal dalam Pembelajaran Matematika}

Dari hasil analisis deskriptif sebagaimana telah diporeh data maka statistik hasil pretest dan Postest siswa untuk materi operasi hitung campuran bilangan bulat disajikan dalam Tabel berikut.

Tabel 2 Hasil Pretest dan Posttest Matematika Siswa

\begin{tabular}{lcc}
\hline Statistik & \multicolumn{2}{c}{ Nilai } \\
\cline { 2 - 3 } & Pretest & Postest \\
\hline Ukuran Sampel & 20 & 20 \\
Skor Ideal & 100 & 100 \\
Skor Rata-rata & 63 & 83,25 \\
Skor Tertinggi & 80 & 100 \\
Skor Terendah & 50 & 50 \\
Rentang Skor & 30 & 50 \\
\hline
\end{tabular}

Jika skor hasil pretest dan postest siswa dikelompokkan kedalam lima kategori, maka diperoleh distribusi frekuensi dan skor persentase yang ditunjukkan pada tabel 2 berikut:

Tabel 3 Distribusi Frekuensi dan Persentase Hasil Pretest dan Posttest Matematika Siswa

\begin{tabular}{cccccc}
\hline \multirow{2}{*}{ Skor } & Kategori & \multicolumn{2}{c}{ Frekuensi } & \multicolumn{2}{c}{ Persentase (\%) } \\
\cline { 3 - 6 } $0 \leq x<55$ & Sangat rendah & 7 & 2 & 35 & Prestest \\
\cline { 3 - 6 } & Rendah & 3 & 2 & 15 & 10 \\
$55 \leq x<65$ & Sedang & 7 & 2 & 35 & 10 \\
$65 \leq x<80$ & Tinggi & 3 & 7 & 15 & 35 \\
$80 \leq x<90$ & Sangat tinggi & 0 & 7 & 0 & 35 \\
$90 \leq x \leq 100$ & \multicolumn{2}{c}{$\mathbf{2 0}$} & $\mathbf{1 0 0}$ & $\mathbf{1 0 0}$ \\
\hline \multirow{2}{*}{ Jumlah } & & &
\end{tabular}

JUDIKDAS: Jurnal Ilmu Pendidikan Dasar Indonesia 
Berdasarkan tabel 3 terlihat bahwa persentase hasil pretest matematika siswa sebelum menggunakan model Problem Based Learning Tipe CPS yakni dari 20 siswa terdapat 7 siswa atau 35\% yang masuk kategori sangat rendah, 3 siswa atau 15\% yang masuk kategori rendah, 7 siswa atau 35\% yang masuk kategori sedang, 3 siswa atau 15\% yang masuk kategori tinggi. Sedangkan persentase skor hasil belajar matematika siswa setelah menggunakan model Problem Based Learning Tipe CPS yakni dari 20 siswa terdapat 2 siswa atau 10\% yang masuk kategori sangat rendah, 2 siswa atau 10\% yang masuk kategori rendah, 2 siswa atau 10\% yang masuk kategori sedang, 7 siswa atau 35\% yang masuk kategori tinggi dan 7 siswa atau 35\% yang masuk dalam kategori sangat tinggi.

Berikut data siswa yang memenuhi kriteria ketuntasan hasil belajar matematika siswa kelas V SD Negeri Bawakaraeng Makassar.

Tabel 4 Kriteria Ketuntasan Hasil Belajar Matematika Siswa

\begin{tabular}{cccccc}
\hline Skor & Kriteria & \multicolumn{2}{c}{ Frekuensi } & \multicolumn{2}{c}{ Persentase (\%) } \\
\cline { 3 - 6 } & & Pretest & Postest & Pretest & Postest \\
\hline $0 \leq x<65$ & Tidak Tuntas & 10 & 4 & 50 & 20 \\
$65 \leq x \leq 100$ & Tuntas & 10 & 16 & 50 & 80 \\
& Jumlah & \multicolumn{2}{c}{$\mathbf{2 0}$} & \multicolumn{2}{c}{$\mathbf{1 0 0}$} \\
\hline
\end{tabular}

Berdasarkan tabel 4 sebelum melakukan perlakuan (pretest) dapat digambarkan bahwa yang mencapai ketuntasan hasil belajar hanya 10 orang dari jumlah keseluruhan 20 orang dengan persentase $50 \%$ sedangkan yang tidak mencapai ketuntasan hasil belajar sebanyak 10 orang dari jumlah keseluruhan 20 orang dengan persentase $50 \%$. Ini menunjukkan bahwa secara klasikal siswa kelas V SD Negeri Bawakaraeng Makassar tidak memenuhi kriteria klasikal dengan presentase rata-rata 50\%. Sedangkan setelah perlakuan (posttest) dengan model Problem Based Learning Tipe CPS dapat digambarkan bahwa yang telah mencapai ketuntasan hasil belajar sebanyak 16 orang dari jumlah keseluruhan 20 orang dengan persentase $80 \%$ sedangkan yang tidak mencapai ketuntasan hasil belajar sebanyak 4 orang dari jumlah keseluruhan 20 orang dengan persentase 20\%. Ini menunjukkan bahwa secara klasikal siswa kelas V SD Negeri Bawakaraeng Makassar dinyatakan telah mencapai KKM.

Berdasarkan uraian diatas dapat disimpulkan bahwa ketuntasan hasil belajar matematika siswa setelah menggunakan model Problem Based Learning Tipe CPS tuntas secara klasikal yaitu mencapai $80 \%$. Dengan demikian, bahwa penerapan model Problem Based Learning Tipe CPS dalam pembelajaran matematika berpengaruh terhadap kemampuan pemecahan masalah matematika siswa kelas V SD Negeri Bawakaraeng Makassar (Wayan \& Nurhayati, 2012).

\section{Aktivitas Siswa dalam Proses Pembelajaran Matematika}

Hasil pengamatan aktivitas siswa dengan menggunakan model Problem Based Learning Tipe CPS selama 4 kali pertemuan dinyatakan dalam persentase yang dapat dilihat pada Tabel 4 berikut: 
Tabel 5 Hasil Observasi Aktivitas Siswa

\begin{tabular}{|c|c|c|c|c|c|c|c|}
\hline \multirow[t]{2}{*}{ No } & \multirow[t]{2}{*}{$\begin{array}{c}\text { Komponen Yang } \\
\text { Diamati }\end{array}$} & \multicolumn{4}{|c|}{$\begin{array}{c}\text { Frekuensi Aktivitas } \\
\text { Siswa Pada } \\
\text { Pertemuan Ke- }\end{array}$} & \multirow[t]{2}{*}{ Rata-Rata } & \multirow{2}{*}{$\begin{array}{c}\text { Persentase } \\
\text { Rata-Rata } \\
\text { Pertemuan } \\
(\%)\end{array}$} \\
\hline & & I & II & III & IV & & \\
\hline \multirow{2}{*}{$\begin{array}{l}1 . \\
2 .\end{array}$} & $\begin{array}{l}\text { Siswa yang hadir pada } \\
\text { saat proses pembelajaran }\end{array}$ & 19 & 19 & 20 & 20 & 20 & 97,5 \\
\hline & $\begin{array}{l}\text { Siswa yang } \\
\text { memperhatikan } \\
\text { penjelasan guru }\end{array}$ & 17 & 19 & 19 & 20 & 19 & 93,75 \\
\hline 3. & $\begin{array}{l}\text { Siswa yang menjawab } \\
\text { pertanyaan lisan guru }\end{array}$ & 15 & 17 & 17 & 19 & 17 & 85 \\
\hline 4. & $\begin{array}{l}\text { Siswa yang mengajukan } \\
\text { pertanyaan tentang } \\
\text { materi yang diajarkan }\end{array}$ & 5 & 8 & 10 & 12 & 19 & 43,75 \\
\hline 5. & $\begin{array}{l}\text { Siswa yang bekerja } \\
\text { mandiri dalam proses } \\
\text { belajar mengajar } \\
\text { berlangsung }\end{array}$ & 19 & 19 & 20 & 20 & 20 & 97,5 \\
\hline & $\begin{array}{l}\text { Siswa yang mengerjakan } \\
\text { pekerjaan rumah (PR) }\end{array}$ & 19 & 19 & 20 & 20 & 20 & 97,5 \\
\hline 7. & $\begin{array}{l}\text { Siswa yang melakukan } \\
\text { aktifitas lain diluar } \\
\text { kegiatan pembelajaran }\end{array}$ & 8 & 7 & 5 & 6 & 7 & 32,5 \\
\hline Rata & Rata & & & & & & 85,83 \\
\hline
\end{tabular}

Berdasarkan tabel 5 dapat dilihat bahwa selama kegiatan pembelajaran dengan menggunakan model pembelajaran Problem Based Learning tipe CPS berlangsung, siswa telah terlibat secara aktif sehingga dominasi guru dalam pembelajaran dapat berkurang. Secara umum, hasil analisis data aktifitas siswa menunjukkan sebagian besar siswa aktif selama pembelajaran berlangsung dapat dilihat bahwa rata-rata persentase aktifitas siswa adalah $85,83 \%$ sedangkan untuk aktifitas negatif hanya 32,5\%. Ini berarti bahwa siswa kelas V SD Negeri Bawakaraeng Makasssar berada pada kategori aktif.

\section{Kesimpulan}

Berdasarkan hasil analisis data dan pembahasan yang telah dikemukakan, maka diambil kesimpulan bahwa penerapan model pembelajaran Problem Based Learning Tipe CPS memberi pengaruh terhadap kemampuan pemecahan masalah matematika pada siswa karena model pembelajaran ini melibatkan siswa dalam memecahkan masalah berkaitan dengan kehidupan sehari-hari, menuntut siswa untuk bermain dan berperan aktif, sehingga dapat meningkatkan kemampuan kognitifnya.

\section{Referensi}

Adelia, C., Gusmawetti, G., \& Nora, Y. (2020). PENERAPAN MODEL PEMBELAJARAN KOOPERATIF TIPE TWO STAY TWO STRAY DALAM PEMBELAJARAN IPA SISWA KELAS IV SDN 34 AIR PACAH PADANG. Jurnal Cerdas Proklamator, 8(1), 46-53. https://doi.org/10.37301/JCP.V8I1.57 
Asikin, M., Asikin, M., \& Pujiadi, -. (2011). PENGARUH MODEL PEMBELAJARAN MATEMATIKA CREATIVE PROBLEM SOLVING (CPS) BERBANTUAN CD INTERAKTIF TERHADAP KEMAMPUAN PEMECAHAN MASALAH PADA SISWA SMA KELAS X. Lembaran Ilmu Kependidikan, 37(1). https:// doi.org/10.15294/lik.v37i1.514

Daniel, F. (2017). Kemampuan Berpikir Kritis Siswa Pada Implementasi Project Based Learning (PJBL) Berpendekatan Saintifik. JPMI (Jurnal Pendidikan Matematika Indonesia), 1(1), 7-13. https:/ / doi.org/10.26737/JPMI.V1I1.76

Fahrudin, F., Netriwati, N., \& Putra, R. W. Y. (2018). Pembelajaran Problem Solving Modifikasi untuk Meningkatkan Kemampuan Pemahaman Konsep Matematis Siswa SMP. Desimal: Jurnal Matematika, 1(2), 181-189. https:// doi.org/10.24042/DJM.V1I2.2556

Ginting, E. B., Purwanto, S. E., \& Faradillah, A. (2019). PENGARUH MODEL PEMBELAJARAN CREATIVE PROBLEM SOLVING (CPS) TERHADAP KEMAMPUAN BERPIKIR KREATIF MATEMATIS SISWA. Gammath: Jurnal Ilmiah Program Studi Pendidikan Matematika, 4(1), 9-16. https://doi.org/10.32528/GAMMATH.V4I1.1567

Rahman, A. F., Pendidikan, M., Fkip, M., Mangkurat, U. L., Brigjen, J., Hasan Basry, H., \& Banjarmasin, K. (2015). Pengaruh Model Creative Problem Solving (CPS) dalam Pembelajaran Matematika terhadap Kemampuan Berpikir Kreatif pada Siswa Sekolah Menengah Pertama. EDU-MAT: Jurnal Pendidikan Matematika, 3(1), 67-74. https:// doi.org/10.20527/EDUMAT.V3I1.631

Sugiyono. (2017). Metode Penelitian Kuantitatif, Kualitatif, dan RED. Alfabeta. https://www.google.co.id/books/edition/Metode_Penelitian_Pendidikan/uTb MDwAAQBAJ?hl=id\&gbpv=1\&dq=sugiyono+metode+penelitian+kuantitatif $+\mathrm{k}$ ualitatif + dan $+r \% 26 d \&$ printsec $=$ frontcover

Suhardi, S. (2019). UPAYA PENINGKATAN HASIL BELAJAR ILMU PENGETAHUAN SOSIAL MELALUI PEMBELAJARAN KOOPERATIF MODEL STAD PADA SISWA KELAS VI.A SD NEGERI 019 GALANG BATAM TAHUN PELAJARAN 2017/2018. E- Jurnal Mitra Pendidikan, 3(3), 443-453. https://ejurnalmitrapendidikan.com/index.php/e-jmp/article/view/522

Wayan, N., \& Nurhayati, E. (2012). Penerapan Pembelajaran Kooperatif Tipe Teams Games Tournament (TGT) Untuk Meningkatkan Motivasi dan Hasil Belajar Siswa Kelas VII D SMP Negeri 2 Kediri Tahun Ajaran 2011/2012. KARMAPATI (Kumpulan Artikel Mahasiswa Pendidikan Teknik Informatika), 1(2), 226-236. https:// doi.org/10.23887/KARMAPATI.V1I2.19537

Winarso, W. (2014). Membangun Kemampuan Berfikir Matematika Tingkat Tinggi Melalui Pendekatan Induktif, Deduktif Dan Induktif-Deduktif Dalam Pembelajaran Matematika. Eduma: Mathematics Education Learning and Teaching, 3(2), 56259. https://doi.org/10.24235/eduma.v3i2.58

Wiratman, A., Mustaji, M., \& Widodo, W. (2019). The effect of activity sheet based on outdoor learning on student's science process skills. Journal of Physics: Conference Series, 1157(2), 022007. https:/ / doi.org/10.1088/1742-6596/1157/2/022007 
68 | Hamdana Hadaming dan Andi Ardhila

--- Halaman ini sengaja dikosongkan --- 